\title{
Yields of Four Cucumber Varieties After Treatment with a Nematocide ${ }^{1}$
}

\author{
A. Pérez López and R. Mendoza Barbosa ${ }^{2}$
}

\section{INTRODUCTION}

Cucumber-growing is becoming popular in Puerto Rico because of interest aroused by many growers and enterprises from the Continent desiring to raise this crop in the Island during the winter months. Although the crop is not well extended over the Island, it has a great potential for export trade, and for the local demand, which is increasing constantly.

Diseases and insects are not a great problem during the growth of this crop because of the development of disease-resistant varieties and new insecticides that control most pests.

But root-nematodes are a problem during the growth of cucumbers. There are several species of parasitic nematodes which parasitize the roots, especially the feeder-roots, i.e. root hairs of the plant, forming nodes inside them and hindering absorption, thus reducing growth and yield.

This experiment was established with the purpose of comparing the effect of nematocide D.D. (dichloropropene, dichloropropane) on the yields of four cucumber varieties.

\section{PROCEDURE}

An experiment was conducted at the Isabela Agricultural Experiment Substation, Isabela, P.R., on a Coto sandy clay soil to determine the response of four cucumber varieties: Puerto Rico 39, Wisconsin SMR 15, Ohio MR 17, and West Indian Gherkin, after treatment with two concentrations, 0 and 46 gallons per acre of D.D. (dichloropropene, dichloropropane).

The experimental design was a split-plot with six replicates. The main plots in each replicate consisted of the four varieties studied and the subplots consisted of the nematocide treatments. A plot consisted of two rows spaced 3 feet in a perpendicular direction, with a total area of $1 / 78$ acre. Plants were fertilized 6 days after sowing with 9-10-5 commercial fertilizer at the rate of 1,000 pounds per acre. D.D. was applied to the soil 14 days

1 Contribution from the Isabela Agricultural Experiment Substation, Isabela, P.R.

2 Assistant Agronomists, Agricultural Experiment Station, University of Puerto Rico, Isabela, P.R. The authors wish to express their sincere thanks to Mr. José Badillo, Research Assistant in Agronomy of the Isabela Substation, for his assistance during this study, and to Mr. A. Cruz Miret, Assistant Agronomist, Agricultural Experiment Station, Río Piedras, P.R. for his help with the statistics. 
before sowing with the Insco pressure applicator, Model C, 6-outlet kit. ${ }^{3}$ As a precautionary measure the experiment was sprayed every week with alternate applications of fungicides Maneb and Zineb to prevent diseases.

Cucumber is a natural cross-pollinated crop. Most of the pollination is carried out by insects $(1,3,4)^{4}$ and because of this the use of insecticides was limited to a minimum in this experiment.

The attributes measured on each plot were total weight of fruits, total number of fruits, yield of fruits larger than $13 / 2$ inches in diameter, weight of fruits between $1 \frac{1}{2}$ and 1 inch in diameter, and fruits under 1 inch in diameter. Fruits were picked every other day.

\section{RESULTS}

The mean fruit yields in hundredweights per acre are presented in table 1. The production for varieties P.R. 39, Wisconsin SMR 15, Ohio MR 17, and West Indian Gherkin was 111, 59, 45, and 9 hundredweights per acre, respectively. P.R. 39 outyielded significantly all other varieties included in this trial. Wisconsin SMR 15 ranked second in production with a significant increase in yield over Ohio SMR-17 and West Indian Gherkin.

Plots treated with D.D. yielded 58 hundredweights per acre as compared with the control which yielded 52 , this difference being significant.

The total number of fruits per variety and the nematocide treatment followed the same pattern as for fruit weight. Therefore, this could be used as an index to measure total yield of these varieties when treated with nematocides.

P.R. 39 and Wisconsin SMR 15 produced at the 1-percent level of significance more fruits above $1 \frac{1}{2}$ inches in diameter than Ohio MR 17. The mean yield was 33,28 , and 17 hundredweights per acre for P.R. 39, Wisconsin SMR 15, and Ohio MR 17, respectively. There was no significant difference between nematocide treatments; however, there was a trend toward higher yield on treated plots.

The mean yield of fruits between $11 / 2$ and 1 inch, and under 1 inch in diameter followed a similar pattern as the one described above. P.R. 39 outyielded significantly Wisconsin SMR 15 and Ohio MR 17 in the production of fruits under 1 inch in diameter. The yields were 20, 8, and 7 hundredweights per acre for P.R. 39, Ohio MR 17, and Wisconsin SMR 15 , respectively. Plots treated with nematocide were significantly better yielders than the controls.

The West Indian Gherkin is a wild species that produces small fruits. Because of this, data on fruit diameter were not recorded for this variety.

${ }^{3}$ Manufactured by Insect Control Sales and Service, Box 152, Candor, N.C. Our mention constitutes no endorsement.

1 Italic numbers in parentheses refers to Literature Cited, p. 139. 
TABLE 1.-Mean yields of 4 cucumber varieties after treatment with 2 concentrations of D.D.

\begin{tabular}{|c|c|c|c|c|c|}
\hline \multirow{2}{*}{ D.D. treatment } & \multicolumn{4}{|c|}{ Data for varieties indicated } & \multirow{2}{*}{ Mean } \\
\hline & P.R. 39 & $\begin{array}{l}\text { Wisconsin } \\
\text { SMR 15 }\end{array}$ & Ohio MR 17 & $\begin{array}{l}\text { West Indian } \\
\text { gherkin }\end{array}$ & \\
\hline \multicolumn{6}{|c|}{ Mean total weight in cwt. per acre ${ }^{1}$} \\
\hline $\begin{array}{r}0 \\
46\end{array}$ & $\begin{array}{l}106 \\
116\end{array}$ & $\begin{array}{l}57 \\
60\end{array}$ & $\begin{array}{l}42 \\
48\end{array}$ & $\begin{array}{r}7 \\
10\end{array}$ & $\begin{array}{l}53 \mathrm{a} \\
59 \mathrm{~b}\end{array}$ \\
\hline Mean & $111 \mathrm{a}$ & $59 \mathrm{~b}$ & 45 & $9 \mathrm{~d}$ & 55 \\
\hline \multicolumn{6}{|c|}{ Mean tolal number of fruits } \\
\hline $\begin{array}{r}0 \\
46\end{array}$ & $\begin{array}{l}1,265 \\
1,426\end{array}$ & $\begin{array}{l}748 \\
823\end{array}$ & $\begin{array}{l}664 \\
747\end{array}$ & $\begin{array}{l}558 \\
774\end{array}$ & $\begin{array}{l}808 \mathrm{a} \\
943 \mathrm{~b}\end{array}$ \\
\hline Mean & $1,345 \mathrm{a}$ & 785 & 705 & $666 b$ & 876 \\
\hline
\end{tabular}

Yield in cwt. per acre of fruits above 11/2-inch diameter

\begin{tabular}{r|c|c|c|c|c}
\hline 0 & 32 & 28 & 15 & - & $25 \mathrm{a}$ \\
46 & 35 & 28 & 19 & - & $27 \mathrm{a}$ \\
\cline { 2 - 5 } Mean & $33 \mathrm{a}$ & $28 \mathrm{a}$ & $17 \mathrm{~b}$ & - & 26 \\
\hline
\end{tabular}

Yield in cwt. per acre of fruits between 11/2 and 1-inch diameter

\begin{tabular}{r|c|c|c|c|c}
\hline 0 & 55 & 23 & 20 & - & $33 \mathrm{a}$ \\
46 & 60 & 25 & 21 & - & $35 \mathrm{a}$ \\
\cline { 2 - 5 } Mean & $58 \mathrm{a}$ & $24 \mathrm{~b}$ & $20 \mathrm{~b}$ & - & 34 \\
\hline
\end{tabular}

Yield in cwt. per acre of fruits under 1-inch diameter

\begin{tabular}{c|c|c|c|c|c}
\hline 0 & 19 & 6 & 7 & - & $10 \mathrm{a}$ \\
46 & 21 & 7 & 8 & - & $12 \mathrm{~b}$ \\
\cline { 2 - 5 } & $20 \mathrm{a}$ & $7 \mathrm{~b}$ & $8 \mathrm{~b}$ & - & 11 \\
\hline
\end{tabular}

1 Mean with same superscript belong to the same level of significance according to the Student Newman-Keuls test (2). 
The total number of fruits and the weight were the only attributes measured.

\section{DISCUSSION}

The native variety P.R. 39, even though it is a slicing type of cucumber, has characteristics such as good yield, adaptability over wide areas in Puerto Rico, and resistance to one of the most important diseases of cucumber, downy mildew, caused by the fungus Pseudoperonospora cubensis (Berk and Curt). These attributes make it a very desirable source of germ plasm for a breeding program to develop good pickling types, or tentatively as a commercial type for pickling, according to a preliminary report (5).

Varieties Wisconsin SMR 15, Ohio MR 17, and West Indian Gherkin, which are pickling types, yielded poorly in this experiment. In general, the yields obtained in this trial compare favorably with those obtained by Rico et al. (6).

Soil treated with D.D. increased yields significantly over the control. These results suggest that soil fumigation for the control of nematode is a sound practice in order to obtain a profitable crop.

\section{SUMMARY}

The behavior of the cucumber varieties P.R. 39, Wisconsin SMR 15, Ohio MR 17, and West Indian Gherkin, after treatment with two concentrations of D.D. (dichloropropene, dichloropropane) was studied in the Isabela area. The following major results were obtained:

1. The variety P.R. 39 produced much more fruit than any of the other varieties studied.

2. Many more fruits were produced in all plots treated with D.D. than in those not treated.

3. Visual observations in the field demonstrated that, as reported by Rico Ballester et al. (6), the P.R. 39 was more resistant to the downy mildew disease than any of the other varieties studied.

\section{RESUMEN}

En el área de Isabela se estudió el efecto de dos concentraciones de D.D. (dichloropropene, dichloropropane) en la producción de cuatro variedades de pepinillos. Los resultados principales de este estudio fueron los siguientes:

1. La variedad P.R. 39 produjo significativamente mucho más frutas que las demás variedades estudiadas.

2. En todas las parcelas tratadas con D.D. se produjo mucho más fruta que en las no tratadas.

3. Observaciones visuales demostraron que la variedad P.R. 39 es más resistente al añublo lanoso que las otras variedades estudiadas. Estos resultados están muy de acuerdo con lo reportado por Rico Ballester (6). 


\section{LITERATURE CITED}

1. Beattie, W. R., Cucumber Growing, USDA Farmer's B. 1563, 1942.

2. Federer, W., Experimental Design, Macmillan Co., New York, N.Y. 1951.

3. Kelsheimer, E. G., Report on the Latest Insecticides and Their Effects upon Honeybees, Fla. Dept. Agr. B. 135, 55, 1950.

4. Parlier, A., personal communication, Parlier Products Corp. Isabela, P.R.

5. Parris, G. K., The Effect of Honeybees in Watermelon Fields on Set of Melons, Fla. Dept. Agr. B. 135, 44-8, 1950.

6. Rico, M., Ramos Caro, C., and Vélez Fortuño, J., An evaluation of pickling cucumber varieties at Isabela Substation, J. Agr. Univ. P.R. 46 (4) 360-2, 1962. 